\title{
SUSTENTABILIDADE E OS PROBLEMAS SOCIOAMBIENTAIS NA SOCIEDADE CONSUMOCENTRISTA
}

\section{SUSTAINABILITY AND SOCIAL AND ENVIRONMENTAL PROBLEMS IN THE CONSUMER CENTER SOCIETY}

\author{
Cleide Calgaro" \\ Liton Lanes Pilau Sobrinho**
}

\section{RESUMO}

No presente trabalho desenvolve-se a pesquisa a partir do seguinte questionamento: como é possível a sustentabilidade minimizar os problemas socioambientais advindos da sociedade de consumocentrista moderna?. Para tal utilizou-se o método analítico com estudos bibliográficos de obras nacionais e estrangeiras. Conclui-se que a sustentabilidade pode ser concretizada e é um viés para minimizar os problemas socioambientais causados pelo mercado e o capitalismo na sociedade consumocentrista, mas para isso, é preciso uma nova racionalidade da espécie humana, na qual se tenha como objetivo a preservação da casa comum, através de uma nova visão ética.

PALAVRAS-CHAVE: Meio ambiente. Problemas socioambientais. Sociedade de consumocentrista. Sustentabilidade.

\begin{abstract}
In the present work the research is developed based on the following question: how is sustainability possible to minimize the social and environmental problems arising from the modern consumer-centric society? For this we used the analytical method with bibliographical studies of national and foreign works. It is concluded that sustainability can be realized and is a bias to minimize the social and environmental problems caused by the market and capitalism in the consumer-centric society, but for this, a new rationality of the human species is needed, aiming to preserve the common home, through a new ethical vision.
\end{abstract}

KEYWORDS: Environment. Social and environmental problems. Consumer-centrist society. Sustainability.

* Doutora em Ciências Sociais na Universidade do Vale do Rio dos Sinos - UNISINOS. PósDoutora em Filosofia e em Direito ambos pela Pontifícia Universidade Católica do Rio Grande do Sul - PUCRS. Doutoranda em Filosofia pela PUCRS, na condição de taxista CAPES. Professora da Graduação e Pós-Graduação em Direito na Universidade de Caxias do Sul. É Líder do Grupo de Pesquisa "Metamorfose Jurídica” da Universidade de Caxias do Sul-UCS e Vice-Líder do Grupo de Pesquisa "Filosofia do Direito e Pensamento Político" da Universidade Federal da Paraíba-UFPB. Atua como pesquisadora no Grupo de pesquisa "Regulação ambiental da atividade econômica sustentável (REGA)" da Escola Superior Dom Helder Câmara. Orcid: https://orcid.org/0000-0002-1840-9598. CV: http://lattes.cnpq. br/8547639191475261. E-mail: ccalgaro1@hotmail.com.

* Professor dos cursos de Mestrado e Doutorado no Programa de Pós-Graduação Stricto Sensu em Ciência Jurídica da Universidade do Vale do Itajaí. Professor do Programa de PósGraduação Stricto Sensu Mestrado em Direito da Universidade de Passo Fundo. Coordenador do PPGDireito da Universidade de Passo Fundo. Pós-doutor em Direito pela Universidade de Sevilha - US. -Espanha. Doutor em Direito pela Universidade do Vale do Rio dos Sinos UNISINOS (2008), Mestre em Direito pela Universidade de Santa Cruz do Sul - UNISC (2000). Possui graduação em Direito pela Universidade de Cruz Alta (1997). Tem experiência na área de Direito, com ênfase em Direito Internacional Ambiental, Direito Constitucional. Orcid: https://orcid.org/0000-0001-5696-4747. Lattes: http://lattes.cnpq.br/2413013286462855. E-mail: litonlanes@gmail.com. 


\section{INTRODUÇÃO}

O presente trabalho tem como problema principal estudar a sustentabilidade como forma de equacionar os problemas socioambientais advindos da sociedade consumocentrista moderna. Para tal utilizou-se o método analítico com estudo de bibliografias nacionais e internacionais para melhor elucidar a questão que está sendo.

Verifica-se que o meio ambiente e a sociedade padecem de problemas tanto sociais como ambientais, aqui denominados socioambientais, devido ao fato de que o mercado e o capital visam o poder econômico e o lucro. Com isso se busca tecer considerações acerca da questão proposta e verificar se é possível uma harmonia entre ser humano/homem ${ }^{1}$ e natureza numa sociedade consumocentrista.

Deste modo, as tecnologias surgem como mecanismos que podem servir para atingir a sustentabilidade e reduzir os problemas socioambientais, mas é preciso que o ser humano busque uma nova racionalidade, a qual ele não seja mais o centro (numa compreensão de mundo com um viés antropocêtrico) e, sim, entenda que vive num sistema no qual a natureza deve ser resguardada.

É preciso uma visão ecocêntrica na qual a casa comum deve ser preservada em sua integralidade, como também é necessária uma racionalidade que busque resguardar o ser humano em sua integralidade, ou seja, reduzindo as desigualdades sociais e outros poblemas que assolam a humanidade na sociedade atual.

\section{A SUSTENTABILIDADE E OS DESAFIOS NO ENFRANTAMENTO DOS PROBLEMAS SOCIAMBIENTAIS NA SOCIEDADE CONSUMOCENTRISTA MODERNA}

A sociedade de consumo se caracteriza hoje pelo consumocentrismo, ou seja, o consumo acaba sendo o centro da mesma. As pessoas vivem em torno do consumo e esquecem que esseconsumo exagerado e desregrado que se torna o hiperconsumismo gera problemas ambientais e sociais severos que precisam ser contidos. O consumo é a "estrela de ouro" do mercado e do capital, no qual as pessoas são induzidas a comprarem o que não precisam e o que não tem necessidade. Dessa forma, concebe-se o mundo do aparentar ser e ter, no qual se tem tudo, mas ao mesmo tempo não se possui nada instituindo-se um vazio paradoxal. Cria-se o "Deus" consumo que tudo pode resolver e trazer a felicidade a vida efêmera do ser humano, que é adestrado e docilizado pelas grandes corporações e pelo mercado. As pessoas acabam cedendo ao consumo criando extratificações e individualizações na sociedade. A vida gira ao

1 Os autores a palavra homem com conotação de ser humano, não havendo diferença qualquer diferença de gênero acerca da questão. 
entorno desse consumo, que acaba sendo o centro da sociedade e da felicidade; consumo esse exagerado que leva ao hiperconsumo; o hiperconsumo leva ao consumocentrismo, que é uma nova categoria que surge na modernidade. $\mathrm{O}$ consumocentrismo vem a ser definido pelo fato do consumo ser o centro principal da sociedade moderna, no qual o mesmo é fonte de poder e adestramento de massas sociais. Assim:

Na sociedade moderna contemporânea, vive-se numa era consumista, em que os sujeitos estão mais ligados a mercadorias e a objetos do que, propriamente, a outros sujeitos, pois os valores funcionais dos objetos fazem com que o sujeito se sinta pertencente à sociedade de consumo - sujeito/objeto - e não à sociedade humana, no sentido de ligação sujeito/sujeito. O consumocentrismo é a dinâmica desse sistema e impõe ao sujeito a disciplina da alimentação, da cultura, da vestimenta, entre outras. Assim, o mesmo caracteriza-se pelo ciclo das mercadorias, que é efêmero, quando o sujeito precisa consumir para se sentir pertencente à sociedade contemporânea. (CALGARO; PEREIRA, 2018, p. 15).

Deste modo, Pereira e Calgaro entendem que "na atualidade, as pessoas não consomem mais por necessidade, mas sim pelo prazer de comprar, seja para satisfazer suas futilidades, ou simplesmente, por consumir" (PEREIRA; CALGARO, 2015, p. 16). O consumo se torna a razão e o centro da sociedade moderna, no qual essa sociedade somente pensa em consumir levando ao consumocentrismo, o qual dessubjetifica o sujeito-consumidor. Debord denota que "o que aparece é bom, o que é bom aparece" (DEBORD, 1997, p. 17). $\mathrm{Na}$ visão de Juvin e Lipovetsky essa cultura do consumismo impõe cultura de marcas, na qual tudo acaba aparecendo em meios de comunicação e em vários locais, fazendo com que as pessoas venham a consumir de forma exacerbada e sendo adestradas por um modelo de vida criado pelo marketing e pelas grandes corporações. De acordo com a visão dos autores, o consumo, hoje: "é uma cultura de consumismo hiperbólico que se impõe igualmente como uma cultura de marcas. Os logotipos são expostos em toda parte e em todos os suportes. Aparecem, por exemplo, por meio do marketing indireto em filmes e séries de TV”. (2012, p.22). Desse forma, os mesmos autores entendem que: "os nomes dos produtos brilham em todas as grandes vias públicas, nos museus patrocinados, nas lojas duty-free de todos os aeroportos do mundo, em todos os sites e endereços da internet". (2012, p.22). Lipovetsky denota que "neste momento de hiperconsumismo o durável cede lugar ao descartável e tudo deve entreter com o mínimo de esforço. O capitalismo e o espírito de fruição estão acabando com a autoridade pública e a dignidade da cultura". (LIPOVETSKY, 2007, p. 57). Importante demonstrar que o consumo tem uma dupla face, pois ao mesmo momento que aproxima os sujeitos, os afasta, os adestra e os aliena.

A coerção vem sendo substituída pela estimulação; pela forte imposição de padrões de comportamento promovidos por sedução; pelo policiamento de 
conduta operado pelas relações públicas e a publicidade; e pela regulação normativa em si, com a criação de novas necessidades e novos desejos (BAUMAN, 2011, p. 39).

A sociedade está em busca de prazer, sendo que esse prazer individualiza os sujeitos e os desarticula, segundo Bauman:

A busca de prazeres individuais articulada pelas mercadorias em oferta, uma busca guiada, sempre redirecionada e reformulada por sucessivas campanhas publicitárias, provê o único substituto aceitável (na verdade, mal-necessitado e acolhido) para a enaltecedora solidariedade de colegas de trabalho e para o calor radiante do cuidar e ser cuidado pelos chegados e queridos em casa e na vizinhança mais próxima (BAUMAN, 2011, p. 46).

Os problemas socioambientais surgem na sociedade consumocentrista, havendo a necessidade de se buscar novas tecnologias com o intuito de vislumbrar alternativas para uma sociedade que seja sustentável. Desta forma, quando se pensa em problemas socioambientais, se visualiza questões de poluição, desmatamentos, mudanças climáticas, degradação ambiental, pobreza, desigualdade social. Os problemas sociais geram os problemas ambientais e vice-versa. Com isso existe a necessidade de se pensar alternativas para atingir a sustentabilidade, na qual as novas tecnologias podem ser um caminho para auxiliar nessa árdua jornada.

Assim sendo, um dos grandes desafios da sustentabilidade perpassam pelas transformações ocorridas no meio ambiente e na sociedade, que em grande parte decorrem das intervenções feitas pelo ser humano no meio ambiente. Várias são as histórias estabelecidas por esta intervenção do ser humano no meio ambiente, nesse sentido Carlson entende que:

[...] a vida modifica de fato, o seu meio ambiente, tem sido relevante em breve. Apenas dentro do momento de tempo representando um século presente é que uma espécie - o Homen - adquiriu capacidade significativa para alterar a natureza de seu mundo. Durante o passado quarto do século, esta capacidade não somente aumentou até atingir inquietante magnitude, mas também se modificou quanto ao caráter. O mais alarmante de todos os assaltos contra o meio ambiente, efetuado pelo Homen, é representado pela contaminação do ar, da terra, dos rios e dos mares, por via de materiais perigosos e até letais. Esta poluição é, em sua maior parte, irremediável; a cadeia de males que ela inicia, não apenas no mundo que deve sustentar a vida, mas também nos tecidos viventes, é em sua maior parte irreversível (CARLSON, 1969, p. 15$16)$.

Em decorrência dessa intervenção constante que o ser humano faz no ambiente, colhe-se os frutos na atualidade e inúmeras são as consequências enfrentadas por todos, como por exemplo, as mudanças climáticas que alteram significativamente os ciclos na Terra. Desse modo, há uma preocupação dos organismos governamentais de estabelecer algumas diretrizes para que se estabeleça uma convivência pacífica entre os seres humanos e o ambiente. A 
convivência se dá no sentido de viver em harmonia e respeito, vislumbrando que se faz parte de um círculo sistêmico, onde tudo está interligado e interconectado.

À vista disso destaca-se o trabalho desenvolvido pela Sra. Gro Harlem Brundtland $^{2}$ como Primeira Ministra da Noruega, que teve importante participação para o desenvolvimento do Relatório Brundtland, o qual veio a estabelecer como diretriz fundamental a proteção ao meio ambiente através do desenvolvimento sustentável, trazendo como um de seus fundamentos que:

1. A Terra é um, mas o mundo não é. Todos nós dependemos de uma biosfera para sustentar nossas vidas. No entanto, cada comunidade, cada país, esforça-se para a sobrevivência e prosperidade com pouca consideração por seu impacto sobre os outros. Alguns consomem recursos da Terra a uma taxa que deixaria pouco para as gerações futuras. Outros, muitos mais em número, consomem muito pouco e vivem com a perspectiva da fome, da miséria, doença e morte precoce. (NAÇÕES UNIDAS, 2016). ${ }^{3}$ [tradução livre].

2 En 1981 se eligió por primera vez a la Sra. Gro Harlem Brundtland como Primera Ministra de Noruega. A la edad de 41, era la persona más joven, además de la única mujer, que había formado gobierno en Noruega. Con otros dos mandatos como Primera Ministra de 1986 a 1989 y de 1990 a 1996, la Dra. Brundtland encabezó el gobierno de Noruega durante más de 10 años. A lo largo de su trayectoria política, la Dra. Brundtland ha fomentado una preocupación creciente en lo que se refiere a las cuestiones de importancia mundial. En 1983 el Sr. Javier Pérez de Cuellar, por aquel entonces Secretario General de las Naciones Unidas, invitó a la Sra. Brundtland a establecer y presidir la Comisión Mundial sobre el Medio Ambiente y el Desarrollo. La Comisión, más conocida por su labor de expansión del concepto político del desarrollo sostenible, publicó su informe Nuestro futuro común en abril de 1987. Las recomendaciones de la Comisión se dirigieron a la Cumbre para la Tierra - Conferencia de las Naciones Unidas sobre el Medio Ambiente y el Desarrollo (CNUMAD) - celebrada en Río de Janeiro en 1992. En mayo de 1998 fue elegida Directora General de la Organización Mundial de la Salud. Ocupó este cargo hasta 2003. La Sra. Gro Harlem Brundtland, que posee el título de Medicina y el master en salud pública (MPH), pasó 10 años trabajando como médico y científica en el sistema de salud pública de Noruega. Durante el decenio de 1970, adquirió el reconocimiento internacional en los círculos medioambientales, así como una reputación política en casa.

Tradução Livre: Em 1981, a Sra. Gro Harlem Brundtland foi eleita Primeira Ministra da Noruega pela primeira vez. Aos 41 anos, ele era a pessoa mais jovem, além da única mulher que havia formado um governo na Noruega. Com dois outros mandatos como primeiroministro de 1986 a 1989 e de 1990 a 1996, o Dr. Brundtland liderou o governo norueguês por mais de 10 anos. Ao longo de sua carreira política, o Dr. Brundtland fomentou crescente preocupação com questões de importância global. Em 1983, o Sr. Javier Pérez de Cuellar, então Secretário Geral das Nações Unidas, convidou Brundtland para estabelecer e presidir a Comissão Mundial sobre Meio Ambiente e Desenvolvimento. A Comissão, mais conhecida por seu trabalho na expansão do conceito político de desenvolvimento sustentável, publicou seu relatório Nosso Futuro Comum em abril de 1987. As recomendações da Comissão foram dirigidas à Cúpula da Terra - Conferência das Nações Unidas sobre o Meio Ambiente. Meio Ambiente e Desenvolvimento (UNCED) - realizado no Rio de Janeiro em 1992. Em maio de 1998, foi eleita Diretora Geral da Organização Mundial de Saúde. Ocupou este cargo até 2003. A Sra. Gro Harlem Brundtland, que detém o título de Medicina e Mestre em Saúde Pública (MPH), passou 10 anos trabalhando como médica e cientista no sistema de saúde pública da Noruega. Durante a década de 1970, ele ganhou reconhecimento internacional nos círculos ambientais, bem como uma reputação política em casa.

(NAÇÕES UNIDAS. Disponível na <http://www.un.org/es/climatechange/2007highlevel/ brundtland.shtml> acessado no dia 3/4/2016).

3 United Nations World Commission on Environment and Development -Brundtland Report 1. The Earth is one but the world is not. We all depend on one biosphere for sustaining our lives. Yet each community, each country, strives for survival and prosperity with little regard 
Se reconhece que os recursos existentes no Planeta são finitos, uma vez que ocorre grande desigualdade de distribuição dos mesmos. Assim, se não houver um cuidado especial com o Planeta, nem todos poderão aproveitar a abundância de recursos, muito menos as futuras gerações. Com isso se ressalta que um dos problemas sociais, no mundo, com maior abrangência é a desigualdade social e a pobreza. Países em desenvolvimento sempre criam uma dependência de países desenvolvidos, os quais possuem a tecnologia e criam novos produtos a partir da matéria-prima que vem dos países em desenvolvimento. Com isso mesmo que os países em desenvolvimento mesmo sendo ricos em matéria-prima, tem a consequência de que o extrativismo destrói tanto o meio ambiente, que como dito possui recursos finitos, como deteriora a sociedade criando maior desigualdade social entre outros problemas. $\mathrm{Na}$ visão de Cechin:

Assim acontece com a economia que não é um sistema isolado, mas sim interage com a natureza. Os bens de consumo são produzidos através de matéria-prima que se extrai da natureza. Está claro que é preciso corrigir esse equívoco e levar em consideração tanto a geração de lixo quanto a dilapidação do capital natural. (CECHIN, 2010, p. 42).

Diante deste processo de evolução da sociedade adverte-se que as maiores transformações ocorridas na natureza perpassam pela atuação humana, onde ao longo dos anos vem degradando-se de forma assustadora o Planeta. Essa degradação feita em nome do poder econômico, no qual se utiliza a tecnologia como forma de manipulação e de benefício para alguns na sociedade consumocentrista. Contudo é preciso buscar a sustentabilidade que é um dos grandes desafios da modernidade. A partir do estabelecimento do relatório de Brundtland é que veio a se consolidar o termo sustentabilidade:

Um dos motivos pelos quais a "sustentabilidade" ganhava cada vez mais adeptos era a própria dificuldade de defini-la. Com a publicação do Relatório Brundtland, em 1987, surge uma definição do conceito de desenvolvimento sustentável com ampla aceitação, que se tornaria quase "oficial": "desenvolvimento sustentável é desenvolvimento que atende às necessidades do presente sem comprometer a capacidade das gerações futuras de atender suas próprias necessidades" (ARANHA, 2006, p.56) ${ }^{4}$.

Observa-se que o legado trazido pelo relatório de Brundtland foi o estabelecimento dos pilares da sustentabilidade que se tratariam plenamente através da

for its impact on others. Some consume the Earth's resources at a rate that would leave little for future generations. Others, many more in number, consume far too little and live with the prospect of hunger, squalor, disease, and early death. (WIKISOURCE. Disponínel na <https:// en.wikisource.org/wiki/Brundtland_Report/Chapter_1._A_Threatened_Future>. Acessado no dia 03/04/2016).

4 Nesta obra o autor cita ALMINO, João. Naturezas Mortas: ecofilosofia das relações internacionais. XX Curso de Altos Estudos do Instituto Rio Branco(mimeo), Brasília, 1990. 
[...] Conferência do Rio (Conferência das Nações Unidas sobre Meio Ambiente e Desenvolvimento, 1992) foi convocada dois anos após a publicação do Relatório Brundtland (elaborado pela Comissão Mundial sobre Meio Ambiente e Desenvolvimento, presidida pela então PrimeiraMinistra da Noruega, Gro Brundtland), cuja ampla divulgação permitiu que novos aspectos enriquecessem o debate em torno do meio ambiente. O relatório introduziu, igualmente, novos enfoques e cunhou o conceito de desenvolvimento sustentável, objetivo que exige equilíbrio entre "três pilares": as dimensões econômica, social e ambiental [grifo nosso]. (ARANHA, 2006, p.18).

Diante desses avanços estabelecidos pelo relatório é que foi possível verificar que atuação do homem, através da voracidade e da ganância econômica, faz com que ocorra uma íntima relação de proteção nos sistemas econômico, social e ambiental, nesse último cabe um apoderamento econômico da economia sobre os demais, explicado por Riechmann, Herrero e Madorrán:

En el plano ecológico parece evidente considerar la inviabilidad de la vida humana y de las sociedades durante mucho tiempo si estas se desarrollan en contradicción con los límites y procesos que las sostienen. Somos seres ecodependientes y como tales vivimos y somos en la naturaleza. En la dimensión social, la sostenibilidad se relaciona con la capacidad de satisfacer las necesidades humanas de forma justa y con la condición de interdependencia que caracteriza a los seres humanos [...]. Desde el punto de vista económico, existen bienes, procesos y trabajos que son los que permiten satisfacer las necesidades de las personas. Sin embargo estas tres patas no son iguales, sino que se asemejan a esas muñecas rusas que encajan unas dentro de otras. (RIECHMANN; REYES; HERRERO; MADORRÁN, 2012, p. 35-36) . $^{5}$

Os tripés das dimensões da sustentabilidade permeiam uma íntima relação de dependência, pois as ações do mercado repercutem sensivelmente no cotidiano da sociedade, que por sua vez trará consequências ao meio ambiente. Desta forma, "la economía de la naturaleza es cíclica, totalmente renovable y autorreproductiva, sin residuos, y cuya fuente de energía es inagotable en términos humanos: la energía solar en sus diversas manifestaciones"6 (RIECHMANN; REYES; HERRERO; MADORRÁN, 2012, p. 35). Essa fonte que a natureza dá ao homem, com a capacidade de auto-renovar-se é espetacular, "en esta economía cíclica natural cada residuo de un proceso se convierte en la matéria

5 No nível ecológico, parece claro considerar a não viabilidade da vida humana e das sociedades por muito tempo se estas se desenvolvem em contradição com os limites e processos que as sustentam. Somos seres dependentes do eco e, como tal, vivemos e estamos na natureza. Na dimensão social, a sustentabilidade está relacionada à capacidade de atender as necessidades humanas de forma justa e com a condição de interdependência que caracteriza os seres humanos [...]. Do ponto de vista econômico, existem bens, processos e empregos que atendem às necessidades das pessoas. No entanto, essas três pernas não são as mesmas, mas lembram aquelas bonecas russas que se encaixam umas nas outras. (Tradução Livre).

6 A economia da natureza é cíclica, totalmente renovável e autoprodutiva, sem desperdício, e cuja fonte de energia é inesgotável em termos humanos: a energia solar em suas diversas manifestações. (Tradução Livre). 
prima de otro: los ciclos se cierran"7 (RIECHMANN; REYES; HERRERO; MADORRÁN, 2012, p. 35). Este processo pertence à criação divina, ou seja, colocando cada coisa no seu lugar. $\mathrm{Na}$ visão de Leff:

A construção da sustentabilidade implica uma ideia e uma visão de futuro que a cegueira da razão positivista é incapaz de ver. Portanto, para isso é necessário abrir o curso da história para uma nova racionalidade - para racionalidades alternativas, para uma ética da outridade e para um diálogo de saberes. (LEFF, 2010, p.72-73).

Partindo dessa visão, todo ser humano interage com seu meio, um é interdependente do outro; não sendo possível ao ser humano viver sem os recursos naturais, sendo um dos seres mais frágeis do Planeta. Contudo para que esse ser humano entenda a interdependência existe a necessidade de uma nova racionalidade socioambiental, onde o mesmo perceba o quanto precisa do meio ambiente e o quanto necessita dos demais seres humanos e não-humanos que habitam essa Terra. Essa racionalidade se pauta em uma ética onde exista a cooperação socioambiental entre seres que são, em tese, razoáveis e racionais e precisam co-habitar o mesmo Planeta e preservá-lo para as presentes e futuras gerações, mas principalmente preservá-lo por si mesmo, por seu valor intrinseco. A vida se perfaz na preservação do humano e do não humano, ou seja, precisase de uma ética ecocêntrica, no qual tudo é preservado, isso quer dizer, a casa comum deve ser respeitada e conservada.

Como se observa a intervenção humana no meio ambiente trouxe consequências nefastas, com um processo que fugiu das mãos dos governantes diante do discurso do progresso a qualquer preço, porém, a cada ação ocorre uma reação, ficando um alerta de atenção em relação à Terra que agoniza. Diante disso, Leff afirma em seus escritos que:

A degradação ambiental, o risco de colapso ecológico e o avanço da desigualdade e da pobreza são sinais eloquentes da crise do mundo globalizado. A sustentabilidade é o significante de uma falha fundamental na história da humanidade; crise de civilização que alcança seu momento culminante na modernidade, mas cujas origens remetem à concepção do mundo que serve de base à civilização ocidental. A sustentabilidade é o tema do nosso tempo, do final do século XX e da passagem para o terceiro milênio, da transição da modernidade truncada e inacabada para uma pós-modernidade incerta, marcada pela diferença, pela diversidade, pela democracia e pela autonomia. O saber ambiental emerge de uma reflexão sobre a construção social do mundo atual, onde hoje convergem e se precipitam os tempos históricos que já não são mais os tempos cósmicos, da evolução biológica e da transcendência histórica. (LEFF, 2001, p.09).

A crise ora anunciada e o risco de um esgotamento dos recursos naturais que se dá em decorrência do avanço das desigualdades vem à tona pela forma

7 Nesta economia cíclica natural, cada resíduo de um processo se torna a matéria prima de outro: os ciclos são fechados. (Tradução Livre). 
de como vive a civilização ocidental, no qual ocorre uma má distribuição dos recursos naturais, com isso se verifica que os problemas socioambientais acabam se agravando na modernidade e que nem mesmo a tecnologia consegue saná-los ou mesmo diminuí-los, visto que o império e a "mão invisível” do mercado e das grandes corporações sobrepujam os mesmos. Para Chomsky:

Os ricos e os poderosos vão sobreviver mas porém os efeitos são muito reais e estão piorando rapidamente à medida em que se marginaliza cada vez mais as pessoas porque não desempenham nenhum papel na obtenção de benefícios, o que está sendo considerado o único valor humano. Bem, os problemas ambientais têm hoje uma escala muito maior do que tiveram no passado. E existe uma alta possibilidade - tão alta que nenhuma pessoa normal a descartaria - de que em duzentos anos o nível de água do mundo haja aumentado até o ponto de destruir a maior parte da vida humana. Muito bem, se não começarmos a fazer algo a respeito agora, não é impossível que isso aconteça. De fato, é bastante provável. Assim, é irrelevante o que eu opine. A resposta é essa: se continuarem marginalizados, não haverá muita história com que se preocupar. Quem sabe se as pessoas vão reagir ou não? Sabem? Temos que decidir entre todos (CHOMSKY, 2012, p.477).

Para que seja possível estabelecer uma organização ponderada para os problemas socioambientais, é de fundamental importância que se restabeleçam as relações entre o crescimento econômico e o meio ambiente para a promoção da sustentabilidade, sendo que para Leff:

O discurso da sustentabilidade busca reconciliar os contrários da dialética do desenvolvimento: o meio ambiente e o crescimento econômico. Este mecanismo ideológico não significa apenas uma volta de parafuso a mais da racionalidade econômica, mas opera uma volta e um torcimento da razão; seu intuito não é internalizar as condições ecológicas da produção, mas proclamar o crescimento econômico como um processo sustentável, firmado nos mecanismos do livre mercado como meio eficaz de assegurar o equilíbrio ecológico e a igualdade social”. (LEFF, 2001, p.26-27).

Essa fala fica mais presente com o estabelecimento da ECO 92, realizada no Rio de Janeiro, no Brasil, onde "a Conferência do Rio consagrou o conceito de desenvolvimento sustentável, e contribuiu para a mais ampla conscientização de que os danos ao meio ambiente eram majoritariamente de responsabilidade dos países desenvolvidos”. (ARANHA, 2006, p.18). Também se evidenciou necessário estabelecer uma política para “[...] os países em desenvolvimento receberem apoio financeiro e tecnológico para avançarem na direção do desenvolvimento sustentável”. (ARANHA, 2006, p.18). Houve uma grande conscientização que os Estados desenvolvidos viessem a ajudar os Estados em desenvolvimento, para aplicarem tecnologia, diminuindo os efeitos da industrialização em relação à poluição gerada ao meio ambiente. Mas, o que se observou é que enquanto se compreender que os problemas relacionados ao meio ambiente são de responsabilidade de apenas alguns Estados, o mundo 
estará fadado ao insucesso, pois não há fronteiras para as questões ambientais, conforme estabelece o $2^{\circ}$ Princípio da Declaração do Rio sobre Meio Ambiente e Desenvolvimento.

Assim, a ECO 92, ocorrida no Rio de Janeiro, no Brasil em 1992, foi a conferência que mais avanços trouxe para a proteção ambiental, podendose citar a Declaração do Rio sobre Meio Ambiente e Desenvolvimento, ${ }^{8} \mathrm{em}$ especial os seus princípios $1^{\circ}, 4^{\circ}, 5^{\circ}, 7^{\circ}, 9^{\circ}, 12,20,21,22,24$ e $27^{9}$. Fica claro

8 A Conferência das Nações Unidas sobre Meio Ambiente e Desenvolvimento, tendo se reunido no Rio de Janeiro, de 3 a 14 de junho de 1992, reafirmando a Declaração da Conferência das Nações Unidas sobre o Meio Ambiente Humano, adotada em Estocolmo em 16 de junho de 1972, e buscando avançar a partir dela, com o objetivo de estabelecer uma nova e justa parceria global mediante a criação de novos níveis de cooperação entre os Estados, os setores-chaves da sociedade e os indivíduos, trabalhando com vistas à conclusão de acordos internacionais que respeitem os interesses de todos e protejam a integridade do sistema global de meio ambiente e desenvolvimento, reconhecendo a natureza integral e interdependente da Terra, nosso lar[...]. (ORGANIZAÇÃO DAS NAÇÕES UNIDAS. Declaração do Rio sobre Meio Ambiente e Desenvolvimento. Disponível em: < https:/www.apambiente.pt/_zdata/ Politicas/DesenvolvimentoSustentavel/1992_Declaracao_Rio.pdf>. Acesso em: 28/01/2019).

9 Princípio 1 - Os seres humanos estão no centro das preocupações com o desenvolvimento sustentável. Têm direito a uma vida saudável e produtiva, em harmonia com a natureza.

Princípio 4 - Para alcançar o desenvolvimento sustentável, a proteção ambiental constituirá parte integrante do processo de desenvolvimento e não pode ser considerada isoladamente deste.

Princípio 5 - Para todos os Estados e todos os indivíduos, como requisito indispensável para o desenvolvimento sustentável, irão cooperar na tarefa essencial de erradicar a pobreza, a fim de reduzir as disparidades de padrões de vida e melhor atender às necessidades da maioria da população do mundo.

Princípio 7 - Os Estados irão cooperar, em espírito de parceria global, para a conservação, proteção e restauração da saúde e da integridade do ecossistema terrestre. Considerando as diversas contribuições para a degradação do meio ambiente global, os Estados têm responsabilidades comuns, porém diferenciadas. Os países desenvolvidos reconhecem a responsabilidade que lhes cabe na busca internacional do desenvolvimento sustentável, tendo em vista as pressões exercidas por suas sociedades sobre o meio ambiente global e as tecnologias e recursos financeiros que controlam.

Princípio 8 - Para alcançar o desenvolvimento sustentável e uma qualidade de vida mais elevada para todos, os Estados devem reduzir e eliminar os padrões insustentáveis de produção e consumo, e promover políticas demográficas adequadas.

Princípio 9 - Os Estados devem cooperar no fortalecimento da capacitação endógena para o desenvolvimento sustentável, mediante o aprimoramento da compreensão científica por meio do intercâmbio de conhecimentos científicos e tecnológicos, e mediante a intensificação do desenvolvimento, da adaptação, da difusão e da transferência de tecnologias, incluindo as tecnologias novas e inovadoras.

Princípio 12 - Os Estados devem cooperar na promoção de um sistema econômico internacional aberto e favorável, propício ao crescimento econômico e ao desenvolvimento sustentável em todos os países, de forma a possibilitar o tratamento mais adequado dos problemas da degradação ambiental. As medidas de política comercial para fins ambientais não devem constituir um meio de discriminação arbitrária ou injustificável, ou uma restrição disfarçada ao comércio internacional. Devem ser evitadas ações unilaterais para o tratamento dos desafios internacionais fora da jurisdição do país importador. As medidas internacionais relativas a problemas ambientais transfronteiriços ou globais deve, na medida do possível, basear-se no consenso internacional.

Princípio 20 - As mulheres têm um papel vital no gerenciamento do meio ambiente e no desenvolvimento. Sua participação plena é, portanto, essencial para se alcançar o desenvolvimento sustentável. 
que estes princípios consagraram efetivamente o desenvolvimento sustentável. Nesse sentido, é importante o posicionamento estabelecido por Leff, o qual prelaciona que "o desenvolvimento sustentável é um projeto social e político que aponta para o ordenamento ecológico e a descentralização territorial da produção. Como para a diversificação dos tipos de desenvolvimento e dos modos de vida das populações que habitam o planeta" (LEFF, 2001, p. 57). Continuando o autor aduz que:

O desenvolvimento sustentável colocou o ser humano no centro de seus objetivos, propondo entre suas metas a qualidade de vida e o desenvolvimento pleno de suas potencialidades. Isto mostra a necessidade de assegurar as condizes mínimas de nutrição e de saúde para uma vida sadia, produtiva e prazerosa para todos. Para consegui-lo, não basta incrementar a cobertura dos atuais serviços de saúde. Os objetivos do desenvolvimento sustentável implicam a necessidade de reconceitualizar a saúde e a doença, de reorientar os serviços de saúde pública e as práticas médicas em novas formas de desenvolvimento. O campo da saúde ambiental questiona a prática individualizada da medicina. Abre um campo mais amplo à saúde pública para atender as condições de saúde das maiorias empobrecidas, mas também as novas doenças de gênese ambiental. Este novo campo da saúde pública obriga a entender as relações da racionalidade social prevalecente, na qual se incluem as práticas médicas e as políticas de saúde pública, com a saúde e a doença”. (LEFF, 2001, p. 311-312).

Uma das coisas que o autor diz é que com o estabelecimento do desenvolvimento sustentável mudou-se o centro de atenção à proteção do meio ambiente, no qual o homem passou a ser este centro. Observa-se o princípio $3^{\mathrm{o} 10}$ da Declaração do Rio sobre Meio Ambiente e Desenvolvimento como uma

Princípio 21 - A criatividade, os ideias e a coragem dos jovens do mundo devem ser mobilizados para criar uma parceria global com vistas a alcançar o desenvolvimento sustentável e assegurar um futuro melhor para todos.

Princípio 22 - Os povos indígenas e suas comunidades, bem como outras comunidades locais, têm um papel vital no gerenciamento ambiental e no desenvolvimento, em virtude de seus conhecimentos e de suas práticas tradicionais. Os Estados devem reconhecer e apoiar adequadamente sua identidade, cultura e interesses, e oferecer condições para sua efetiva participação no atingimento do desenvolvimento sustentável.

Princípio 24 - A guerra é, por definição, prejudicial ao desenvolvimento sustentável. Os Estados irão, por conseguinte, respeitar o direito internacional aplicável à proteção do meio ambiente em tempos de conflitos armados e irão cooperar para seu desenvolvimento progressivo, quando necessário.

Princípio 27 - Os Estados e os povos irão cooperar de boa fé e imbuídos de um espírito de parceria para a realização dos princípios consubstanciados nesta Declaração, e para o desenvolvimento progressivo do direito internacional no campo do desenvolvimento sustentável. [grifo nosso]. (ORGANIZAÇÃO DAS NAÇÕES UNIDAS. Declaração do Rio sobre Meio Ambiente e Desenvolvimento. Disponível em: < https:/www.apambiente.pt/_zdata/Politicas/ DesenvolvimentoSustentavel/1992_Declaracao_Rio.pdf>. Acesso em: 28/01/2019).

10 Princípio 3 - O direito ao desenvolvimento deve ser exercido de modo a permitir que sejam atendidas equitativamente as necessidades de desenvolvimento e de meio ambiente das gerações presentes e futuras. [grifo nosso] (ORGANIZAÇÃO DAS NAÇÕES UNIDAS. Declaração do Rio sobre Meio Ambiente e Desenvolvimento. Disponível em: < https://www.apambiente. pt/zdata/Politicas/DesenvolvimentoSustentavel/1992_Declaracao_Rio.pdf>. Acesso em: 
garantia das gerações presentes e futuras, no mesmo sentido a Constituição da República Federativa do Brasil de 1988 em seu art. 225 $5^{11}$, já tinha estabelecido igual proteção. A ECO 92 trouxe muitos avanços e criou um compromisso para o estabelecimento de políticas públicas, através da Agenda 21. Em decorrência disso, no Brasil criou-se a Comissão do Desenvolvimento Sustentável, ao qual Aranha relata:

Ao final da Conferência do Rio, o Brasil apoiaria outra decisão que seria interpretada como uma nova demonstração de enfraquecimento do PNUMA: a criação da Comissão de Desenvolvimento Sustentável (CDS) “para monitorar os progressos realizados na implementação da Agenda 21 e das atividades relacionadas com a integração dos objetivos de meio ambiente e desenvolvimento em todo o sistema das Nações Unidas". Na realidade, como recorda o Ministro Everton Vargas, Diretor do Departamento de Meio Ambiente e Temas Especiais do Ministério das Relações Exteriores, "tendo em vista que o PNUMA não tem mandato na área de desenvolvimento, a CDS foi criada como forma de dar maior perfil político e de reunir as várias agências e órgãos das Nações Unidas que tratam das matérias relacionadas ao desenvolvimento sustentável.” ** (ARANHA, 2006, p.18). ${ }^{12}$

A partir da Agenda 21 estabeleceu-se um compromisso para que fosse criada uma estratégia em cada país, para controlar internamente e colocar em prática os objetivos estabelecidos por esta Conferência. É importante destacar uma realidade demonstrada pela referida Agenda, a de que:

\begin{abstract}
Nos países industrializados, os padrões de consumo das cidades representam uma pressão muito séria sobre o ecossistema global, ao passo que no mundo em desenvolvimento os assentamentos humanos necessitam de mais matériaprima, energia e desenvolvimento econômico simplesmente para superar seus problemas econômicos e sociais básicos. Em muitas regiões do mundo, em especial nos países em desenvolvimento; as condições dos assentamentos humanos vêm se deteriorando, sobretudo em decorrência do baixo volume de investimentos no setor, imputável às restrições relativas a recursos com que esses países se deparam em todas as áreas. Nos países de baixa renda sobre os quais há dados recentes, apenas 5,6 por cento do orçamento do Governo central, em média, foram dedicados a habitação, lazer, seguridade social e bem estar social (ORGANIZAÇÃO DAS NAÇÕ̃ES UNIDAS, 2016) ${ }^{13}$.
\end{abstract}

\title{
28/01/2019).
}

11 Artigo 225. Todos têm direito ao meio ambiente ecologicamente equilibrado, bem de uso comum do povo e essencial à sadia qualidade de vida, impondo-se ao poder público e à coletividade o dever de defendê-lo e preservá-lo para as presentes e futuras gerações. BRASIL. Constituição da República Federativa do Brasil. Disponível em: < http://www.planalto.gov.br/ ccivil_03/constituicao/constituicaocompilado.htm>. Acesso em: 27/01/19.

12 O Autor faz referências a duas declarações de proteção ao meio Ambiente *MINISTÉRIO DAS RELAÇÕES EXTERIORES. Relatório da Delegação do Brasil: Conferência das Nações Unidas sobre Meio Ambiente e Desenvolvimento. p. 25.**86 CONFERÊNCIA DAS NAÇỐS UNIDAS SOBRE MEIO AMBIENTE E DESENVOLVIMENTO. Agenda 21. Parágrafo 38.13(a).

13 Ver em: Organização das Nações Unidas. Agenda 21. Capítulo 7, p.71. Disponível na <http:// www.onu.org.br/rio20/img/2012/01/agenda21.pdf>. Acessado no dia 4/4/2016. 
Adverte-se que as realidades existentes no mundo são extremamante desiguais, principalmente pela concentração de renda nos países industrializados, outra realidade visível nos países em desenvolvimento, em decorrência da falta de investimentos nas questões vitais para garantia do bem comum. Nesse sentido, Harvey, diz que:

A produção implica uma concentração geográfica de dinheiro, meios de produção e força de trabalho. Esses elementos são reunidos em um lugar específico, onde uma nova mercadoria é produzida. São então enviados para fora, para mercados nos quais serão vendidos e consumidos. A proximidade dos meios de produção, da força de trabalho e dos mercados de consumo reduz custos e aumenta o lucro em locais privilegiados. (HARVEY, 2011, p.131).

Portanto, fica evidente que uma das formas estabelecidas pelo modus operandi da produção é exatamente a redução de custos, pouco importando a que custo isso seja conquistado, o lucro pelo menor custo. Por isso, observa-se de certo modo uma centralização da produção em países periféricos, onde as desigualdades e limitações de direitos são mais evidentes. Bosselmann entende que:

Existem três grandes problemas com o modelo das duas escalas. Primeiro, porque pressupõe uma separarão entre as esferas ambiental e de desenvolvimento que não existe na realidade. O desenvolvimento não é uma entidade estática, nem o meio ambiente. $\mathrm{O}$ objetivo real do desenvolvimento sustentável, trazer ambas as esferas em conjunto, não pode ser refletido em um modelo que visa o equilíbrio das duas entidades separadas. Em segundo lugar, a dimensão de tempo, tão essencial para a sustentabilidade, está faltando no modelo preocupado com o equilíbrio presente. [...] Terceiro, a teoria da igual importância é tão ideologicamente tendenciosa. Ela reflete a equação liberal e neoliberal do desenvolvimento com crescimento econômico e prosperidade. Essa equação não é necessariamente relevante para todos os povos que vivem agora, por exemplo, no "Sul”, ou no futuro. (BOSSELMANN, 2015, p. 51$52)$.

Diante das tranformações ocorridas no meio ambiente em decorrência das ações humanas, é fundamental que os Organismos Internacionais chamem a atenção dos Estados. Nessa seara, fez-se necessária a criação de outro mecanismo na ECO 92, que foi a Carta da Terra, a qual, segundo Aranha:

No tocante ao que viria a ser a "Declaração do Rio", a intenção original de Maurice Strong, expressa na primeira Sessão do Comitê Preparatório, era de que emanasse da Conferência do Rio uma "Carta da Terra" (Earth Charter) texto de apenas uma página, em linguagem simples. Ao final da IV Sessão do Comitê Preparatório, entretanto, chegou-se ao texto final de um documento de poucas páginas que conseguia resumir, com surpreendente concisão, muitas das mais importantes questões que dividem os interesses e preocupações dos países desenvolvidos, em desenvolvimento e com economias em transição. Intitulado "Declaração do Rio", o documento - que representava equilíbrio tão delicado que não sofreu alterações na própria Conferência -, contém 27 
princípios que passaram a ser invocados com freqüência e inspiraram extensa literatura interpretativa. (ARANHA, 2006, p.82-83).

Este documento trouxe em seu Prêambulo ${ }^{14}$ a preocupação com a situação da Terra, já alertando que toda humanidade que habita o planeta Terra se encontra em uma situação caótica. Da mesma forma, a Carta faz referência à Situação Global ${ }^{15}$, reafirma a preocupação com os padrões globais de mutação, "que afetam quase todos os aspectos do que fazemos. Para bem ou para mal, estamos sendo impelidos rumo a uma ordem global que ninguém compreende plenamente, mas cujos efeitos se fazem sentir sobre todos nós" (GIDDENS, 2003, p. 108). Urge que se estabeleçam medidas efetivas, por isso pode-se observar a importância do estabelecimento de normas, como prepondera Habermas, o qual afirma que:

O sistema global possui um grau maior de legitimidade do que as normas jurídicas singulares. Dreier estatui a seguinte condição necessária para a validade jurídica de um sistema de direitos: “em primeiro lugar, ele precisa ter eficácia na sociedade e, em segundo, tem que ser justificado eticamente; ao passo que a validade jurídica de normas particulares depende de uma legalização conforme a uma constituição que satisfaça aos critérios apresentados; além disso, essas normas jurídicas devem revelar por si mesmas um mínimo de eficácia social, ou chance de eficácia, bem como um mínimo de justificativa ética, ou seja, capacidade de justificativa”. (HABERMAS, 2003, p.51).

Constata-se que a partir do estabelecimento de normas internacionais, cria-se uma necessidade de os Estados signatários adotarem em seus sistemas jurídicos locais o mesmo sentido que a Carta da Terra traz, ou seja, uma preocupação com a vida no Planeta, que a partir do desenvolvimento sustentável,

14 Preâmbulo - Estamos diante de um momento crítico na história da Terra, numa época em que a humanidade deve escolher o seu futuro. À medida que o mundo torna-se cada vez mais interdependente e frágil, o futuro enfrenta, ao mesmo tempo, grandes perigos e grandes promessas. Para seguir adiante, devemos reconhecer que, no meio da uma magnífica diversidade de culturas e formas de vida, somos uma família humana e uma comunidade terrestre com um destino comum. Devemos somar forças para gerar uma sociedade sustentável global baseada no respeito pela natureza, nos direitos humanos universais, na justiça econômica e numa cultura da paz. Para chegar a este propósito, é imperativo que nós, os povos da Terra, declaremos nossa responsabilidade uns para com os outros, com a grande comunidade da vida, e com as futuras gerações. (BRASIL, Ministério do Meio Ambiente. Carta da Terra. Disponível na <http://www.mma. gov.br/estruturas/agenda21/_arquivos/carta_terra.pdf>. Acessado no dia 4/4/2016).

15 A Situação Global. Os padrões dominantes de produção e consumo estão causando devastação ambiental, redução dos recursos e uma massiva extinção de espécies. Comunidades estão sendo arruinadas. Os benefícios do desenvolvimento não estão sendo divididos eqüitativamente e o fosso entre ricos e pobres está aumentando. A injustiça, a pobreza, a ignorância e os conflitos violentos têm aumentado e são causa de grande sofrimento. $O$ crescimento sem precedentes da população humana tem sobrecarregado os sistemas ecológico e social. As bases da segurança global estão ameaçadas. Essas tendências são perigosas, mas não inevitáveis. (BRASIL, Ministério do Meio Ambiente. Carta da Terra. Disponível na <http://www.mma.gov. br/estruturas/agenda21/_arquivos/carta_terra.pdf>. Acessado no dia 4/4/2016). 
também foi protegido nos princípios 5. a; 11 e $14^{16}$. Diante deste processo evolutivo de proteção ao meio ambiente, fica evidente que a Conferência do Rio trouxe avanços. De acordo com Aranha:

A Conferência do Rio foi, sob os mais diversos pontos de vista, um grande sucesso. Vinte anos após Estocolmo, o mundo parecia pronto a colocar o meio ambiente entre os temas prioritários da agenda mundial. A perspectiva de que o desenvolvimento sustentável seria a base de um novo paradigma da cooperação internacional, no entanto, revelou-se ilusória, uma vez que o processo de globalização se sobrepôs. O desenvolvimento sustentável não é necessariamente incompatível com a globalização: para muitos, ao contrário, a preocupação com o meio ambiente é uma das conseqüências da globalização. Entretanto, vários aspectos apontam para as dificuldades que a globalização representa para a tentativa de se impor o desenvolvimento sustentável como novo paradigma, como a incompatibilidade entre o crescimento das empresas transnacionais e a mudança dos padrões de produção e consume (ARANHA, 2006, p.86-87).

O grande problema ocasionado pelos avanços da Conferência é a sua efetivação, que para sua implementação requer custos e quem vai pagar esta conta? Será que os Estados estão dispostos a pagar essa conta? Essa mudança estrutural depende de uma quebra de paradigma, onde o meio ambiente deve voltar para o centro das atenções, mas na realidade fica para um segundo plano e para uma nova rodada de negociações, como foi a Cúpula de Joanesburgo, que conforme relata Aranha:

Pela Resolução 55/199 da Assembléia Geral das Nações Unidas, intitulada "Revisão decenal do progresso alcançado na implementação dos resultados da Conferência das Nações Unidas sobre Meio Ambiente e Desenvolvimento”, foi convocada a Cúpula Mundial sobre Desenvolvimento Sustentável em 2002. O consenso político obtido na Conferência do Rio em torno do conceito de desenvolvimento sustentável parecia haver criado uma sólida base para a colocação em prática das recomendações da Agenda 21. Avanços inegáveis ocorreram nas áreas de conhecimento científico, progresso tecnológico e

16 Princípios estabelecidos pela Carta da Terra sobre o desenvolvimento sustentável. Princípios: 5. Proteger e restaurar a integridade dos sistemas ecológicos da Terra, com especial preocupação pela diversidade biológica e pelos processos naturais que sustentam a vida. (BRASIL, Ministério do Meio Ambiente. Carta da Terra. Disponível na <http:/www.mma.gov.br/estruturas/ agenda21/_arquivos/carta_terra.pdf>. Acessado no dia 4/4/2016).

a. Adotar planos e regulamentações de desenvolvimento sustentável em todos os níveis que façam com que a conservação ambiental e a reabilitação sejam parte integral de todas as iniciativas de desenvolvimento.

11. Afirmar a igualdade e a eqüidade de gênero como pré-requisitos para o desenvolvimento sustentável e assegurar o acesso universal à educação, assistência de saúde e às oportunidades econômicas.

14. Integrar, na educação formal e na aprendizagem ao longo da vida, os conhecimentos, valores e habilidades necessárias para um modo de vida sustentável.

a. Oferecer a todos, especialmente a crianças e jovens, oportunidades educativas que lhes permitam contribuir ativamente para o desenvolvimento sustentável. (BRASIL, Ministério do Meio Ambiente. Carta da Terra. Disponível na http://www.mma.gov.br/estruturas/agenda21/_ arquivos/carta_terra.pdf. Acessado no dia 4/4/2016). 
envolvimento do setor privado, ao mesmo tempo em que, na maioria dos países, se fortaleceu a legislação ambiental e cresceram a informação e a participação da sociedade civil. Diante das expectativas criadas no Rio, no entanto, o Secretário-Geral das Nações Unidas, Kofi Annan, reconheceria, um mês antes de Joanesburgo, que "the record in the decade since the Earth Summit is largely one of painfully slow progress and a deepening global environmental crisis". (ARANHA, 2006, p.87).

Como se ressaltou acima, as questões econômicas e tecnológicas prevalecem sobre o meio ambiente e a sociedade. Assim impera o poder do mercado e das grandes corporações, sendo que a sustentabilidade fica num segundo plano. A sociedade evolui, as pessoas evoluiram com o passar do tempo, mas essa evolução permeou por um processo de implementação de um novo modelo de desenvolvimento estabelecido para os Estados, que veio a ser denominado como globalização, que segundo Giddens:

A globalização tem algo a ver com a tese de que agora vivemos todos num único mundo - mas exatamente de que maneira, e é essa idéia realmente válida? Diferentes pensadores adotaram opiniões quase diametralmente opostas sobre a globalização em debates que pipocaram ao longo dos últimos anos. Alguns questionam tudo o que se refere a ela. Eu os chamarei de céticos. (GIDDENS, 2003, p.18).

Percebe-se que este processo cria uma ideia de unidade para o processo de desenvolvimento, pois “com a globalização e por meio da empiricização da universalidade que ela possibilitou, estamos mais perto de construir uma filosofia das técnicas e das ações correlatas, que seja também uma forma de conhecimento [...]” (SANTOS, 2009, p.33), que para Milton Santos, se caracteriza como uma das etapas da Globalização. "Debemos tomar conciencia de que la globalización constituye al mismo tiempo lo mejor y lo peor que ha podido sucederle a la humanidad" ${ }^{17}$ (HESSEL; MORIN, 2012, p.16). Portanto, Hessel e Morin, advertem que a Globalização não necessariamente mostra a face da bondade, mas sim a face da perversidade. Nesse sentido, Santos fala sobre como é vendida a ideia de Globalização:

De fato, se desejamos escapar à crença de que esse mundo assim apresentado é verdadeiro, e não queremos admitir a permanência de sua percepção enganosa, devemos considerar a existência de pelo menos três mundos num só. O primeiro seria o mundo tal como nos fazem vê-lo: a globalização como fábula; o segundo seria o mundo tal como ele é: a globalização como perversidade; e o terceiro, o mundo como ele pode ser: uma outra globalização. (SANTOS, 2009, p.18).

A ideia estabelecida por Santos comunga do pensamento de Morin e Hessel, de que a Globalização tem várias faces, mas qual será a melhor delas?

17 Devemos estar conscientes de que a globalização é, ao mesmo tempo, a melhor e a pior que poderia ter acontecido à humanidade. (Tradução Nossa). 
E para quem? Será que a globalização é positiva ou negativa, em quais pontos? Percebe-se que ela tem que ser boa para todos e não só para alguns. A globalização deve ser boa também para a sociedade e o meio ambiente e não somente para o mercado e o poder econômico, dessa maneira tem-se o posicionamento de Santos, que traz uma ideia inicial de globalização como fábula, segundo a qual:

[...] visto como fábula, erige como verdade um certo número de fantasias, cuja repetição, entretanto, acaba por se tornar uma base aparentemente sólida de sua interpretação [...] A máquina ideológica que sustenta as ações preponderantes da atualidade é feita de peças que se alimentam mutuamente e põem em movimento os elementos essenciais à continuidade do sistema. Damos aqui alguns exemplos. Esses poucos exemplos, recolhidos numa lista interminável, permitem indagar se, no lugar do fim da ideologia proclamado pelos que sustentam a bondade dos presentes processos de globalização, não estaríamos, de fato, diante da presença de uma ideologização maciça, segundo a qual a realização do mundo atual exige como condição essencial o exercício de fabulações. (SANTOS, 2009, p. 19-20).

Assim sendo percebe-se que venderam uma ideia de facilitação ao mercado, porém, num dado momento as pessoas ascendem a esta nova realidade, mas por quanto tempo? E será que ascendem mesmo a essa realidade? Logo a globalização vai mostrar a sua verdadeira identidade, dessa forma, Rifkin entende que:

El carácter físico de la economía se reduce. Si la era industrial se caracterizaba por la acumulación de capital y de propiedad física, en la nueva era lo estimable son las formas intangibles de poder que se presentan en paquetes de información y en activos intelectuales. El hecho es que se avanza en la desmaterialización de los productos físicos que durante largo tiempo fueron la medida de la riqueza en el mundo industrial. $(2000, \text { p. } 20)^{18}$.

Isto demonstra uma mudança do modus operandi do sistema capitalista, que tinha como propósito a acumulação do capital e da propriedade física, no entanto buscaram não ter esta dependência e sim, se deterem à informação e à propriedade industrial. Portanto, observa-se a outra cara da globalização, ou seja, sua perversidade:

De fato, para a grande maior parte da humanidade a globalização está se impondo como uma fábrica de perversidades. O desemprego crescente tornase crônico. A pobreza aumenta e as classes médias perdem em qualidade de vida. O salário médio tende a baixar. A fome e o desabrigo se generalizam em todos os continentes. Novas enfermidades como a SIDA se instalam e velhas doenças, supostamente extirpadas, fazem seu retorno triunfal. A mortalidade infantil permanece, a despeito dos progressos médicos e da informação. A educação de qualidade é cada vez mais inacessível. Alastram-se

18 A natureza física da economia é reduzida. Se a era industrial foi caracterizada pelo acúmulo de capital e propriedade física, na nova era as estimáveis são as formas intangíveis de poder que são apresentadas em pacotes de informações e em ativos intelectuais. $O$ fato é que estão sendo feitos progressos na desmaterialização de produtos físicos que por muito tempo foram a medida da riqueza no mundo industrializado. (Tradução Livre). 
e aprofundam-se males espirituais e morais, como os egoísmos, os cinismos, a corrupção. A perversidade sistêmica que está na raiz dessa evolução negativa da humanidade tem relação com a adesão desenfreada aos comportamentos competitivos que atualmente caracterizam as ações hegemônicas. Todas essas mazelas são direta ou indiretamente imputáveis ao presente processo de globalização. (SANTOS, 2009, p.19-20).

Vislumbra-se que este processo de globalização como perversidade traz a verdadeira face do capitalismo parasitário, que é efetivamente o jeito de levar vantagem a qualquer preço. Do mesmo modo tem-se o endendimento de Harvey, que prelaciona:

O capital não é uma coisa, mas um processo em que o dinheiro é perpetuamente enviado em busca de mais dinheiro. Os capitalistas, aqueles que põem esse processo em movimento, assumem identidades muito diferentes. Os capitalistas financistas se preocupam em ganhar mais dinheiro emprestando a outras pessoas em troca de juros". [...] No decorrer do tempo, os capitalistas tem procurado controlar o trabalho, colocando trabalhadores individuais em concorrência uns com os outros para os postos de trabalho em oferta. [...] Tornam-se ferramentas por meio das quais os capitalistas administram a oferta de trabalho em conjunto com os setores privilegiados da força de trabalho que usam o racismo e o machismo para minimizar a competição". (2011, p.41-57).

Esta relação estabelecida entre dinheiro/juros, trabalho/oferta, pode ser estabelecida numa visão de codificação, pois possuem íntima relação de um código binário, fazendo uma relação com o futuro democracia, que para Luhmann é:

Aunque todo el mundo habla de democracia, faltan, sin embargo, concepciones lo suficientemente precisas sobre este código, debemos distinguir entre un valor positivo, <<gobierno >>, y un valor negativo, <<oposición >>. Aunque cada valor se refleja en el otro y existe una relación recíproca, la estructura es asimétrica - o, si quiere, simétrica y asimétrica a la vez. Su genialidad reside también en que evita el ejercicio conjunto de gobierno y oposición según el modelo de los cónsules romanos, y a pesar de todo es capaz de simultanear la estructura binaria. La oposición está también presente en todo lo que el gobierno hace, del mismo modo que la oposición se orienta siempre a partir del gobierno - ¿de quién si no? Precisamente porque no gobiernan ambos, porque no existe entonces ninguna imposición de un consenso, es instructivo el código ${ }^{19}$. (2002, p.164).

19 Embora todos falem de democracia, há, no entanto, concepções precisas e suficientes sobre esse código, devemos distinguir entre um valor positivo, $<<$ governo $>>$, e um valor negativo, < oposição >>. Embora cada valor seja refletido no outro e haja uma relação recíproca, a estrutura é assimétrica - ou, se preferir, simétrica e assimétrica ao mesmo tempo. Seu gênio também reside em que ele evita o exercício conjunto de governo e oposição de acordo com o modelo dos cônsules romanos e, apesar de tudo, ele é capaz de combinar a estrutura binária. A oposição também está presente em tudo o que o governo faz, da mesma forma que a oposição sempre se concentra no governo - de quem mais? Precisamente porque eles não governam ambos, porque não há imposição de um consenso, o código é instrutivo. (Tradução Livre). 
Verifica-se que uma das formas que se utiliza é a da comunicação como um meio dentro do processo de Globalização, ao qual coloca Luhmann, numa relação de governo, para o estabelecimento de um consenso do que verdadeiramente ela deveria ser, que para Castells:

No es para nada evidente que las formas más salvajes de instrumentalización del "capital humano" sean las más adaptadas a las exigencias den nuevo modo de producción. Si el trabajador está obligado a dar pruebas de flexibilidad, de polivalencia, de sentido de la responsabilidad, de espíritu de iniciativa y de capacidad de adaptación a los cambios, ¿puede comportarse de semejante modo sin un mínimo de seguridad y protecciones? ¿El trabajo está condenado a seguir siendo la principal "variable de ajuste" para maximizar los beneficios? Se empiezam a vislumbrar los primeros esbozos, incluso los medios de administración empresarial y patronales, de cierta toma de conciencia de los efectos contrarios a la productividad del burn out de los trabajadores, como también de los efectos destructivos en el seno de las culturas empresariales de reestructuraciones o de modos de administración exclusivamente regidos por lógicas financieras [...]. Por otro lado, tampoco es evidente que la relación de fuerzas tan globalmente desfavorable para los asalariados desde hace unos veinte años en un contexto dominado por el desempleo masivo siga siendo el mismo en el futuro, entre otras por razones demográficas. ${ }^{20}$ (2004, p.109111).

O processo de exploração estabelecido pela Globalização deveria trazer outras formas de redução das desigualdades sociais e não um distanciamento, cada vez maior, entre os ricos e pobres. $\mathrm{Na}$ atualidade esse distanciamento se intensifica cada vez mais, onde se valoriza mais o ter do que o ser. Então, para ser possível estabelecer uma nova visão do que deveria ser este processo, o qual deveria ser o inverso, ou seja, buscar-se-ia a proposta que Santos aduz:

Uma outra globalização supõe uma mudança radical das condições atuais, de modo que a centralidade de todas as ações seja localizada no homem. Sem dúvida, essa desejada mudança apenas ocorrerá no fim do processo, durante o qual reajustamentos sucessivos se imporão. Nas presentes circunstâncias, conforme já vimos, a centralidade é ocupada pelo dinheiro, em suas formas mais agressivas, um dinheiro em estado puro sustentado por uma informação ideológica, com a qual se encontra em simbiose. Daí a brutal distorção do sentido da vida em todas as suas dimensões, incluindo o trabalho e o lazer,

20 Não é de modo algum evidente que as formas mais loucas de instrumentalização do “capital humano" sejam as mais adaptadas às exigências de um novo modo de produção. Se o trabalhador é obrigado a dar provas de flexibilidade, versatilidade, um senso de responsabilidade, um espírito de iniciativa e capacidade de adaptação às mudanças, ele pode se comportar de tal maneira sem um mínimo de segurança e proteção? O trabalho é condenado a permanecer a principal "variável de ajuste" para maximizar os lucros? Começamos a vislumbrar os primeiros esboços, incluindo os meios de gerenciamento corporativo e do empregador, de uma certa conscientização dos efeitos do desgaste dos trabalhadores em relação à produtividade, bem como dos efeitos destrutivos dentro das culturas de negócios da empresa. modos de reestruturação ou gestão exclusivamente regidos pela lógica financeira [...]. Por outro lado, não é evidente que a relação de forças tão globalmente desfavorável para os trabalhadores por cerca de vinte anos em um contexto dominado pelo desemprego em massa permaneça a mesma no futuro, entre outras razões demográficas. (Tradução Livre). 
e alcançando a valoração íntima de cada pessoa e a própria constituição do espaço geográfico. Com a prevalência do dinheiro em estado puro como motor primeiro e último das ações, o homem acaba por ser considerado um elemento residual. Dessa forma, o território, o Estado-nação e a solidariedade social também se tornam residuais. A primazia do homem supõe que ele estará colocado no centro das preocupações do mundo, como um dado filosófico e como uma inspiração para as ações. Dessa forma, estarão assegurados o império da compaixão nas relações interpessiur, estímulo à solidariedade social, a ser exercida entre indivíduo. A nova paisagem social resultaria do abandono e da superação do modelo atual e sua substituição por um outro, capaz de garantir para o maior número a satisfação das necessidades essenciais a uma vida humana digna, relegando a uma posição secundária necessidades fabricadas, impostas por meio da publicidade e do consumo conspícuo. (2009, p. 147-148).

A relação proposta por Santos, que almejou uma nova condição de possibilidade, ou seja, por uma outra globalização inclusiva, que venha realmente reduzir as desigualdades sociais criando forma de inclusão e não exclusão. " $\mathrm{Na}$ base da longa cadeia da oferta que traz os meios de produção para o capitalismo, esconde-se um problema mais profundo de limites naturais em potencial. $\mathrm{O}$ capitalismo como, qualquer outro modo de produção, baseia-se no usufruto da natureza". (HARVEY, 2011, p.41). Em decorrência do desfrute e da utlização da natureza, definido mera mercadoria, há necessidade de se estabelecer um novo cenário para as transformações da sociedade. Este protagonismo se esperava com a Rio+20, a qual ocorreu de 20 a 22 de junho de 2012, “O Futuro Que Nós Queremos”, porém não trouxe os avanços esperados, conforme relata Dowbor:

Há naturalmente também os documentos oficiais. Podem deixar-nos irritados pelas insuficiências ou timidez, mas de toda forma são leituras necessárias. No plano geral, está o documento base aprovado na Rio+20, o chamado The Future we Want, (O Futuro que Queremos) disponível em várias línguas (em espanhol em particular) no site: http://www.uncsd2012.org/thefuturewewant. html. [...] Acho que foi o "mínimo denominador comum" possível de ser alcançado entre os 188 países signatários. Está centrado, como se sabe, "na busca da economia verde no contexto do desenvolvimento sustentável e erradicação da pobreza". Afirma também "a nossa decisão de fortalecer o marco institucional do desenvolvimento sustentável”. e apresenta 26 grandes desafios (segurança alimentar, água, energia, cidades, etc.) É um importante instrumento de construção de consensos. Como há fortes debates sobre o que significa "economia verde", é útil lembrar a definição do PNUMA: tratase de um desenvolvimento que resulta em "improved human well-being and social equity, while significantly reducing environmental risks and ecological scarcities", portanto bem-estar humano, equidade social, redução dos riscos ambientais e da escassez ecológica. Como a definição é abrangente, aqui também me parece que o problema não está no 'verde', e sim no 'como' se atinge os objetivos, na linha da cosmética corporativa ou das mudanças substantivas. (DOWBOR, 2016). ${ }^{21}$ [grifo do autor]

21 Consultar: DOWBOR, Ladislau. Entender a Rio+20: balanços e compromissos. Disponível na: <http://dowbor.org/2012/05/8972.html/>. Acessado no dia 10/04/2016. 
Mais uma vez o foco da Conferência foi o desenvolvimento sustentável, porém não trouxe a evolução esperada do que a Eco92 trouxe no campo de convenções. Por outro lado, em decorrência da crise econômica o foco mudou para a questão econômica, que resolveram inovar com o enfoque para a economia verde, conforme o item 56 do documento "o Futuro que nós queremos", trazendo-a como norte:

Afirmamos que existem diferentes abordagens, visões, modelos e ferramentas disponíveis para cada país, de acordo com suas circunstâncias e prioridades nacionais, para alcançar o desenvolvimento sustentável nas suas três dimensões, que é o nosso objetivo primordial. Neste sentido, consideramos a economia verde, no contexto do desenvolvimento sustentável e da erradicação da pobreza, como uma das importantes ferramentas, disponíveis para alcançar o desenvolvimento sustentável, que poderia oferecer opções para decisão política, sem ser um conjunto rígido de regras. Ressaltamos que a economia verde deve contribuir para a erradicação da pobreza e para o crescimento econômico sustentável, reforçar a inclusão social, melhorando o bem-estar humano, e criar oportunidades de emprego e trabalho digno para todos, mantendo o funcionamento saudável dos ecossistemas da Terra. (ONU, 2019) ${ }^{22}$ [grifo nosso].

Este expediente traz como inovação para a concretização das dimensões da sustentabilidade a economia verde, como meio a ser alcançado para o desenvolvimento e concretização do futuro que se quer. Mas por outro lado, deve-se observar que "o esgotamento e a degradação da Terra e dos chamados recursos naturais não fazem mais sentido no longo prazo do que a destruição dos poderes coletivos de trabalho, pois ambos estão na raiz da produção de toda a natureza”. (HARVEY, 2011, p.41). A economia verde é, sim, um instrumento importante para dirimir os efeitos da degradação ambiental, porém não existe uma solução mágica, mas acredita-se que através educação ambiental possa se estabelecer um novo vínculo de conexão para salvar o Planeta. Por outro lado, o pensamento de Boff quanto ao assunto:

A questão central nem é salvar a Terra. Ela se salva a si mesma e, se for preciso, nos expulsando de seu seio. Mas como nos salvamos a nós mesmos e a nossa civilização? Esta é real questão que a maioria dá de ombros, especialmente os que tratam da macroeconomia. A produção de baixo de carbono, os produtos orgânicos, energia solar e eólica, a diminuição, o mais possível, de intervenção nos ritmos da natureza, a busca da reposição dos bens utilizados, a reciclagem, tudo que vem sob o nome de economia verde são os processos mais buscados e difundidos. E é recomendável que esse modo de produzir se imponha. Mesmo assim não devemos nos iludir e perder o sentido critico. Fala-se de economia verde para evitar a questão da sustentabilidade que se encontra em oposição ao atual modo de produção e consumo. Mas no fundo, trata-se de medidas dentro do mesmo paradigma de dominação da natureza.

22 Ver em: Organização das Nações Unidas. O Futuro que nós queremos. Disponível na <http:// www.mma.gov.br/port/conama/processos/61AA3835/O-Futuro-que-queremos1.pdf, p.11>. Acesso em: 28/01/2019. 
Não existe o verde e o não verde. Todos os produtos contem nas várias fases de sua produção, elementos tóxicos, danosos à saúde da Terra e da sociedade. Hoje pelo método da Análise do Ciclo de Vida podemos exibir e monitorar as complexas inter-relações entre as várias etapas, da extração, do transporte, da produção, do uso e do descarte de cada produto e seus impactos ambientais. (BOFF, 2016). ${ }^{23}$ [grifo nosso].

Há uma necessidade urgente de mudança estrutural, não se pode transformar a natureza em produto. Será que o mercado criou consciência ambiental, ou é somente a criação de um novo nicho de mercado? Os avanços criados pelas inovações tecnológicas dão uma nova condição de possibilidade, que é produzir respeitando o meio ambiente, onde se torna possível por meio da Terceira Revolução Industrial que segundo Rifking:

[...] tendrá un impacto tan significativo en el siglo XXI y la Segunda el XX. Y, exactamente igual que en las dos revoluciones industriales previas, cambiará de manera fundamental todos los aspectos de nuestra forma de trabajar y de vivir [...].Los pilares de la TRI son concretamente cinco: 1) la transición hacia la energía renovable; 2) la transformación del parque de edificios de cada continente en microcentrales eléctricas que recojan y reaprovechen in situ las energías renovables; 3) el despliegue de la tecnología del hidrógeno y de otros sistemas de almacenaje energético en todos los edificios, y a lo largo y ancho de la red de infraestructuras, para acumular energías como las renovables, que son de flujo intermitente; 4) el uso de la tecnología de Internet para transformar la red eléctrica de cada continente en una «interred» de energía compartida que funcione exactamente igual que Internet (millones de edificios podrán generar localmente -in situ- pequeñas cantidades de energía y podrán vender los excedentes que reingresen en la red, compartiendo esa electricidad con sus vecinos continentales), y 5) la transición de la actual flota de transportes hacia vehículos de motor eléctrico con alimentación de red y/o con pilas de combustible, capaces de comprar y vender electricidad dentro de una red eléctrica interactiva continental de carácter inteligente ${ }^{24}$. (2012, p.60).

A mudança de paradigma do documento da Rio+20 propõe uma nova nirada para o desenvolvimento sustentável, ou seja, uma nova ideia de

23 Consultar em: BOFF, Leonardo. A ilusão de uma economia verde. Disponível na: <https:// leonardoboff.wordpress.com/2011/10/16/a-ilusao-de-uma-economia-verde/>. Acessado no dia: 04/04/2016.

$24[\ldots]$ terá um impacto tão significativo no século 21 e o segundo no $20^{\circ}$. E, assim como nas duas revoluções industriais anteriores, mudar fundamentalmente todos os aspectos do nosso modo de trabalhar e viver [...] Os pilares do TRI são cinco: 1) a transição para a energia renovável; 2) a transformação do parque construtivo de cada continente em usinas elétricas que coletam e reutilizam as energias renováveis in situ; 3) a implantação da tecnologia do hidrogénio e de outros sistemas de armazenamento de energia em todos os edifícios e em toda a rede de infraestruturas, para acumular energias como as energias renováveis, que são intermitentes; 4) o uso da tecnologia da Internet para transformar a rede de energia de todos os continentes em uma energia "Interred" compartilhada que funciona exatamente como Internet (milhões de edifícios irá gerar localmente-in situ pequenas quantidades de energia e pode vender excedentes re-entrar na rede, compartilhando a eletricidade com os seus vizinhos continentais), e 5) a transição da frota de transporte de corrente para o motor de veículo elétrico com alimentação e / ou células de combustível, capaz de comprar e vender eletricidade dentro de uma rede elétrica interativa continental inteligente. (Tradução Livre) 
sustentabilidade, que é a inclusão da economia verde, a qual só será possível a sua implementação pelos mecanismos colocados na Terceira Revolução Instrustrial proposta nas palavras de Rifkin, ou seja, pela tecnologia. Espera-se que a tecnologia seja usada com o intuito de preservação ambiental e social, para que as presentes e as futuras gerações e, principalmente, a natureza possa ter uma esperança de não ser tão explorada e degradada. É preciso compreender que se é um todo, onde existe a interdependência de humanos e não-humanos.

\section{CONSIDERAÇÕES FINAIS}

A sociedade vive pautada em bem de consumo (consumocentrismo), o qual é o "Deus" da modernidade, para produzir e vender esses bens de consumo, se utiliza de todas as estratégias, onde o mercado se torna voraz com o meio ambiente e com a sociedade, esquecendo-se que a natureza em sua totalidade precisa ser preservada. A ideia de sustentabilidade vem sendo apregoada a tempo, mas se verifica que a mesma é deixada de lado em prol do interesse econômico do mercado e do capital. É preciso encontrar uma forma da sociedade, do capital e da natureza conviver em harmonia, também, é preciso que se respeite os ciclos vitais da natureza, visto que a mesma possui recursos naturais que são finitos.

As tecnologias devem ser utilizadas em prol da sociedade e da natureza a fim de se atingir realmente a sustentabilidade como forma primordial de defesa da vida em todas as suas formas. Mas para isso existe a necessidade de uma nova racionalidade socioambiental, onde uma visão ecocêntrica, seja efetivada para a proteção da casa comum. Com isso se poderá entender que o ser humano/ homem não é o centro do universo e muito menos o consumo, mas que existe a necessidade de se preservar o meio ambiente natural. Preservação essa que pode ser atingida com o auxílio da tecnologia, que na atualidade e no futuro irá predominar, visto que o ser humano, a cada dia, torma-se extremamente dependente da mesma.

Dessa forma, com a tecnologia, meio ambiente, sociedade, ser humano e mercado devem buscar uma interrelação sistêmica, de maneira que, os mesmos interajam em prol do bem e da casa comum. Uma nova racionalidade e uma nova ética devem se firmar como centro da sociedade consumocentrista, sendo que o ser humano deve compreender que se não houver a presenvação do meio ambiente pelo seu valor intrínseco, não haverá planeta para se viver. A sustentabilidade não deve ser uma bandeira mercadológica e sim uma forma implementar o respeito aos ciclos vitais da natureza. Também existe a necessidade de se diminuir a pobreza e a desigualdade social que afrontam a sociedade consumocentrista moderna, é preciso que a dignidade humana seja efetivada a todos de forma indistinta. 
A vida se faz entre humanos e não-humanos, por isso, a casa comum deve ser preservada e a sustentabilidade, a nova racionalidade humana e a ética juntamente com a tecnologia podem ser o caminho para isso.

\section{REFERÊNCIAS}

ALMINO, João. Naturezas Mortas: ecofilosofia das relações internacionais. XX Curso de Altos Estudos do Instituto Rio Branco(mimeo), Brasília, 1990. ARANHA, André Correa do Lago. ESTOCOLMO, RIO, JOANESBURGO. O Brasil e as três conferências ambientais das Nações Unidas. Brasília: FUNAG, 2006.

ARANHA, André Correa do Lago. ESTOCOLMO, RIO, JOANESBURGO. O Brasil e as três conferências ambientais das Nações Unidas. Brasília: FUNAG, 2006.

BAUMAN, Zygmunt. A ética é possível num mundo de consumidores? Tradução de Alexandre Werneck. Rio de Janeiro: Zahar, 2011.

BOFF, Leonardo. A ilusão de uma economia verde. Disponível na: <https:// leonardoboff.wordpress.com/2011/10/16/a-ilusao-de-uma-economia-verde/>. Acessado no dia: 04/04/2016.

BRASIL, Ministério do Meio Ambiente. Carta da Terra. Disponível na <http:// www.mma.gov.br/estruturas/agenda21/_arquivos/carta_terra.pdf $>$. Acessado no dia 4/4/2016.

BRASIL, Ministério do Meio Ambiente. Disponível em: <http://www.mma.gov. br/port/conama/processos/61AA3835/O-Futuro-que-queremos1.pdf>

BRASIL. Constituição da República Federativa do Brasil. Disponível em: < http://www.planalto.gov.br/ccivil_03/constituicao/constituicaocompilado. htm>. Acesso em: 27/01/19.

BOSSELMANN, Klaus. O princípio da sustentabilidade. Tradução Phillip Gil França. São Paulo: Revista dos Tribunais, 2015.

CARLSON, Rachel. Primavera Silenciosa. Tradução: Raul de Polillo, São Paulo: Ed. Melhoramentos, 1969.

CASTEL, Robert. La inseguridad social: ¿qué es estar protegido? Traducción Viviana Ackerman. Buenos Aires: Manantial, 2004.

CECHIN, Andrei. A natureza como limite da economia: a contribuição de Nicholas Georgescu-Roegen. São Paulo: Editora Senac São Paulo/Edusp, 2010.

CALGARO, Cleide; PEREIRA, Agostinho Oli Koppe Pereira. O constitucionalismo latino-americano e a sociedade consumocentrista: por uma 
democracia socioecológica. In. Direito socioambiental [recurso eletrônico] organização Cleide Calgaro. - Caxias do Sul, RS: Educs, 2018.

CHOMSKY, Avram Noam. ESSENCIAL. Tradução de Jorge Vigil.Título Original: Understanding Power.The Indispensable Chomsky. Barcelona: Austral, 2012.

Declaração do Rio sobre Meio Ambiente e Desenvolvimento. Disponível na <http://www.onu.org.br/rio20/img/2012/01/rio92.pdf>. Acessado no dia 4/4/2016.

DEBORD, Guy. A sociedade espetáculo: comentários sobre a sociedade do espetáculo. Rio de Janeiro: Contraponto Editora, 1997.

DOWBOR, Ladislau. Entender a Rio+20: balanços e compromissos. Disponível na: http://dowbor.org/2012/05/8972.html/. Acessado no dia 10/04/2016.

GIDDENS, Anthony. Mundo em descontrole: o que a globalização está fazendo de nós. Tradução de Maria Luiza X. de A. Borges. Editora Recorde, Rio de Janeiro: 2003.

HABERMAS, Jürgen. Direito e democracia: entre facticidade e validade. v. I. Tradução Flávio Beno Siebeneichler. Rio de Janeiro: Tempo Brasileiro, 2003.

HARVEY, David. O enigma do capital e as crises do capitalismo. Tradução de João Alexandre Peschanski. São Paulo: Boitempo, 2011.

HESSEL, Stéfhane; MORIN, Edgar. El camino de la esperanza: uma llama a la movilización cívica. Traducción de Rosa Alapont. Barcelona: Ediciones Destino, 2012.

JUVIN, Hervé; LIPOVETSKY, Gilles. A globalização ocidental: controvérsia sobre a cultura planetária. Barueri, SP: Manole, 2012. Disponível em: <https:// ucsvirtual.ucs.br/startservico/PEA/>. Acesso em: 05 abr. 2016.

LEFF, Enrique. Discursos sustentáveis. Tradução de Silvana Cobucci Leite. São Paulo: Cortez, 2010.

LEFF, Enrique. Saber ambiental: sustentabilidade, racionalidade, complexidade, poder. Vozes, 2001.

LIPOVESTY, Gilles. A felicidade paradoxal: ensaio sobre a sociedade de hiperconsumo. Tradução de Maria Lucia Machado. São Paulo: Companhia das Letras, 2007.

LIPOVESTY, Gilles. O Império do Efêmero: A moda e seu Destino nas Sociedades Modernas. São Paulo: Companhia das Letras, 1989. 
LIPOVETSKY, Gilles. A sociedade da decepção. Barueri, SP: Manole, 2007. Disponível em: <https://ucsvirtual.ucs.br/startservico/PEA/>. Acesso em: 05 abr.

LUHMANN, Niklas. El futuro de la democracia. In: . Teoría política en el estado de bienestar. Madrid: Alianza Editorial, 2002.

NAÇÕES UNIDAS. Disponível na <http://www.un.org/es/ climatechange/2007highlevel/brundtland.shtml>. acessado no dia 3/4/2016.

O HARVEY, David. O enigma do capital e as crises do capitalismo. Tradução de João Alexandre Peschanski. São Paulo: Boitempo, 2011.

ONU. Disponível na http://www.onu.org.br/rio20/img/2012/01/rio92.pdf. Acessado no dia 4/4/2016.

ORGANIZAÇÃO DAS NAÇÕES UNIDAS. Agenda 21. Capítulo 7, pg.71. Dispinível na <http://www.onu.org.br/rio20/img/2012/01/agenda21.pdf>. Acessado no dia 4/4/2016.

ORGANIZAÇÃO DAS NAÇÕES UNIDAS. Declaração do Rio sobre Meio Ambiente e Desenvolvimento. Disponível em: < https://www.apambiente. pt/_zdata/Politicas/DesenvolvimentoSustentavel/1992_Declaracao_Rio.pdf>. Acesso em: 28/01/2019.

ORGANIZAÇÃO DAS NAÇÕES UNIDAS. O Futuro que nós queremos.

Disponível na <http://www.mma.gov.br/port/conama/processos/61AA3835/OFuturo-que-queremos1.pdf , p.11>. Acesso em: 28/01/2019.

PEREIRA, Agostinho Oli Koppe; CALGARO, Cleide. A modernidade e o hiperconsumismo: políticas públicas para um consumo ambientalmente sustentável. In: PEREIRA, Agostinho Oli Koppe; HORN, Luiz Fernando Del Rio (Orgs.). Relações de consumo: políticas públicas. Caxias do Sul, RS: Plenum, 2015.

RIECHMANN, Jorge; REYES, Luis González; HERRERO, Yayo; MADORRÁN, Carmen. Qué hacemos hoy cuando nos encontramos frente a la amenaza de una crisis mayor que la económica: la ecológica. Madrid: Ediciones Akal, S. A., 2012.

RIFKIN, Jeremy. La Tecera Revolución Industrial. Cómo el poder lateral está transformando la energia, la economia y el mundo. Traducción: Albino Santos Mosquera. Barcelona: Paidós, 2012.

RIFKIN. Jeremy. La era del acceso. La revolución de la nueva economía. Madrid: Paídos, 2000.

SANTOS, Boaventura se Sousa. Rio + 20 e a Cúpula dos Povos. P.3.Disponível na: $<$ http://www.boaventuradesousasantos.pt/media/Boaventura \%20Rio+20\%20 
e\%20a\%20Cupula \%20dos\%20Povos\%20PT11\%20de\%20Fev2012.pdf>. Acessado no dia 04/04/2016.

SANTOS, Milton. Por uma outra globalização: do pensamento único à conscientização universal. 18. ed. Rio de Janeiro/São Paulo: Record, 2009.

WIKISOURCE. disponível em: <https://en.wikisource.org/wiki/Brundtland_ Report/Chapter_1._A_Threatened_Future>. Acessado no dia 03/04/2016. 
